\title{
Quick reference guide
}

\section{Vancouver Citing \& Referencing Style}

Vancouver is a numbered referencing style commonly used in medicine and science, and consist of:

- citation to someone else's work in the text, indicated by the use of a number;

- a sequentially numbered reference list at the end of the document providing full details of the corresponding in-text reference.

It follows rules established by the International Committee of Medical Journal Editors, now maintained by the U.S. National Library of Medicine. It is also known as Uniform Requirements for Manuscripts submitted to Biomedical Journal.

\section{In-text citations}

- Insert an in-text citation:

o when your work has been influenced by someone else's work, for example:

- when you directly quote someone else's work

- when you paraphrase someone else's work

- The general rule of an in-text citation:

o A number is allocated to a source in the order in which it is cited in the text. If the source is referred to again, the same number is used.

o Use Arabic numerals $(1,2,3,4,5,6,7,8,9)$.

o Either square [] or curved brackets () can be used as long as it is consistent.

o Superscripts can also be used rather than brackets. For example, ...was discovered. ${ }^{1,3}$ For consistency Majalah Kedokteran Andalas has chosen to use superscripts in our articles.

o Reference numbers should be inserted to the left or inside of colons and semicolons.

o Reference numbers are generally placed outside or after full stops and commas. For consistency Majalah Kedokteran Andalas is placing reference numbers after full stops.

\section{Multiple works by the same author:}

Each individual work by the same author, even if it is published in the same year, has its own reference number. 


\section{Citing secondary sources:}

A secondary source, or indirect citation, occurs when the ideas on one author are published in another author's work, and you have not accessed or read the original piece of work. Cite the author of the work you have read and also include this source in your reference list.

\section{In-text citation examples}

The in-text citation is placed immediately after the text which refers to the source being cited: ...as one author has put it "the darkest days were still ahead". ${ }^{1}$

The author's name can also be integrated into the text:

Scholtz ${ }^{1}$ has argued that...

\section{Citing more than one reference at a time:}

The preferred method is to list each reference number separated by a comma, or by a dash for a sequence of consecutive numbers. There should be no spaces between commas or dashes.

For example, ...working hours. ${ }^{1,5,8-12}$

\section{Reference List}

- References are listed in numerical order, and in the same order in which they are cited in the text. The reference list appears at the end of the paper.

- The reference list should include all and the only those references you have cited in the text. However, do not include unpublished items such as correspondence.

- Use Arabic numerals (1,2,3,4,5,6,7,8,9).

- Abbreviate journal titles in the style used in the NLM Catalog.

- Check the reference details against the actual source - you are indicating that you have read a source when you cite it.

- Be consistent with your referencing style across the document.

\section{Scholarly journal articles}

- Follow these examples closely for all layout, punctuation, spacing, and capitalization. These general rules apply to both print and electronic articles.

- Enter author's surname followed by no more than 2 initials (full stop).

- If more than 1 author: give all authors' names and separate each by a comma and space.

- For articles with 1 to 6 authors, list all authors. For articles with more than 6 authors, list the first 6 authors then add 'et al.'

- Only the first word of the article title and words that normally begin with a capital letter are capitalized. 


\section{MAJALAH KEDOKTERAN ANDALAS}

- Journal titles are abbreviated (to decipher/find correct abbreviations see: $\underline{\text { PubMed }}$ Journals Database.

- Follow the date with a semi-colon (;).

- Abbreviate months to their first 3 letters (no full stop).

- Give the volume number (no space) followed by issue number in brackets.

- If the journal has continuous page numbering through its volumes, omit month/issue number.

- Abbreviate page numbers where possible, eg: 123-29.

\section{Digital Object Identification (DOI) and URLS}

The digital object identification (DOI) is a unique identifier and should be provided in the reference where it is available. This alphanumeric string is usually located on the first page with other referencing elements in the article. More recent electronic journal articles will be displayed as permanent URLS. They will look something like this: http://dx.doi.org/10.1037/a0024996. Both formats are acceptable, use the form as it appears in your source.

\section{Print articles}

\begin{tabular}{|l|l|}
\hline $\begin{array}{l}\text { Article with } 1 \text { or } 6 \\
\text { authors }\end{array}$ & $\begin{array}{l}\text { Author AA, Author BB, Author CC, Author DD. Title of article. } \\
\text { Abbreviated title of the journal. Date of publication YYYY Mon } \\
\text { DD; volume number(issue number):page numbers. }\end{array}$ \\
\hline $\begin{array}{l}\text { Article with more } \\
\text { than } 6 \text { authors } \\
\text { before dementia. Arch Neurol. 2005 Jan;62(1):112-6. }\end{array}$ & $\begin{array}{l}\text { Author AA, Author BB, Author CC, Author DD, Author EE, Author FF, } \\
\text { et al. Title of article. Abbreviated title of the journal. Date of } \\
\text { publication YYYY Mon DD;volume number(issue number):page } \\
\text { numbers. }\end{array}$ \\
\hline & $\begin{array}{l}\text { Hallal AH, Amortegui JD, Jeroukhimov IM, Casillas J, Schulman Cl, } \\
\text { Manning RJ, et al. Magnetic resonance cholangiopancreatography } \\
\text { accurately detects common bile duct stones in resolving gallstone } \\
\text { pancreatitis. J Am Coll Surg. 2005 Jun;200(6):869-75. }\end{array}$ \\
\hline
\end{tabular}

\section{Electronic journal articles}

- The word [internet] in square brackets should be inserted after the abbreviated journal title.

- The date cited [in square brackets] must be included after the date of publication.

- The URL (web address) must be included at the end of the reference.

- For electronic journal articles with a DOI, include the DOI at the end of the reference, after the URL. 


\begin{tabular}{|c|c|}
\hline $\begin{array}{l}\text { Electronic journal } \\
\text { article }\end{array}$ & $\begin{array}{l}\text { Author AA, Author BB. Title of article. Abbreviated title of Journal } \\
\text { [Internet]. Date of publication YYYY MM [cited YYYY Mon DD]; volume } \\
\text { number(issue number):page numbers. Available from: URL }\end{array}$ \\
\hline & $\begin{array}{l}\text { Stockhausen L, Turale S. An explorative study of Australian nursing } \\
\text { scholars and contemporary scholarship. J Nurs Scholarsh [Internet]. } \\
2011 \text { Mar [cited } 2013 \text { Feb 19];43(1):89-96. Available from: } \\
\text { http://search.proquest.com.ezproxy.lib.monash.edu.au/docview/858 } \\
241255 \text { ?accountid=12528 }\end{array}$ \\
\hline $\begin{array}{l}\text { Electronic journal } \\
\text { article with DOI }\end{array}$ & $\begin{array}{l}\text { Author AA, Author BB, Author CC, Author DD, Author EE, Author FF. } \\
\text { Title of article. Abbreviated title of Journal [Internet]. Year of } \\
\text { publication [cited YYYY Mon DD]; volume number(issue number):page } \\
\text { numbers. Available from: URL DOI }\end{array}$ \\
\hline & $\begin{array}{l}\text { Kanneganti P, Harris JD, Brophy RH, Carey JL, Lattermann C, Flanigan } \\
\text { DC. The effect of smoking on ligament and cartilage surgery in the } \\
\text { knee: a systematic review. Am J Sports Med [Internet]. } 2012 \text { Dec } \\
\text { [cited } 2013 \text { Feb 19];40(12):2872-8. Available from: } \\
\text { http://ajs.sagepub.com/content/40/12/2872 DOI: } \\
\text { 10.1177/0363546512458223. }\end{array}$ \\
\hline
\end{tabular}

\section{Books and books chapter}

- Follow these example closely for all layout, punctuation, spacing, and capitalization.

- Give author's surname followed by no more than 2 initials.

- Give all authors' names and separate each by a comma and space.

- Enter all authors' names in the order in which they appear in the original source.

- Only the first word of the article title and words that normally begin with a capital letter are capitalized.

- For book chapters abbreviate page numbers to p. eg p. 12-25. Where appropriate abbreviate thus: p. 122-8.

- For electronic books include the DOI if it is given and place it after the URL.

- Abbreviate months to their first 3 letters.

- The format for Tables and Figures can also be applied to charts, photographs, graphs, etc.

\begin{tabular}{|c|c|}
\hline $\begin{array}{l}\text { Book: } \\
\text { a) Print book } \\
\text { OR } \\
\text { b) Electronic } \\
\text { book }\end{array}$ & $\begin{array}{l}\text { a) Author AA. Title of book. \# edition [if not first]. Place of } \\
\text { Publication: Publisher; Year of publication. Pagination. } \\
\text { b) Author AA. Title of web page [Internet]. Place of Publication: } \\
\text { Sponsor of Website/Publisher; Year published [cited YYYY Mon DD]. } \\
\text { Number of pages. Available from: URL DOI: (if available) }\end{array}$ \\
\hline & $\begin{array}{l}\text { a) Carlson BM. Human embryology and developmental biology. 4th } \\
\text { ed. St. Louis: Mosby; } 2009.541 \text { p. } \\
\text { b) Shreeve DF. Reactive attachment disorder: a case-based approach } \\
\text { [Internet]. New York: Springer; } 2012 \text { [cited } 2012 \text { Nov 2]. } 85 \text { p. } \\
\text { Available from: }\end{array}$ \\
\hline
\end{tabular}




\begin{tabular}{|l|l|}
\hline & $\begin{array}{l}\text { http://ezproxy.lib.monash.edu.au/login?url=http://dx.doi.org/10.100 } \\
\text { 7/978-1-4614-1647-0 }\end{array}$ \\
\hline $\begin{array}{l}\text { Chapter: } \\
\text { a) in an edited } \\
\text { book } \\
\text { OR } \\
\text { b) in an edited } \\
\text { electronic book }\end{array}$ & $\begin{array}{l}\text { a) Author AA, Author BB. Title of chapter. In: Editor AA, Editor BB, } \\
\text { editors. Title of book. \# edition. Place of Publication: Publisher; Year } \\
\text { of publication. p. [page numbers of chapter]. } \\
\text { b) Author AA, Author BB. Title of chapter. In: Editor AA, Editor BB, } \\
\text { editors. Title of the book [Internet]. Place of publication: Publisher's } \\
\text { name; Year of publication. [cited YYYY Mon DD]. p. \#. [page or } \\
\text { chapter number/s]. Available from: URL DOI [if available] }\end{array}$ \\
\hline & $\begin{array}{l}\text { a) Blaxter PS, Farnsworth TP. Social health and class inequalities. In: } \\
\text { Carter C, Peel JR, editors. Equalities and inequalities in health. 2nd ed. } \\
\text { London: Academic Press; 1976. p. 165-78. } \\
\text { b) Halpen-Felsher BL, Morrell HE. Preventing and reducing tobacco } \\
\text { use. In: Berlan ED, Bravender T, editors. Adolescent medicine today: a } \\
\text { guide to caring for the adolescent patient [Internet]. Singapore: } \\
\text { World Scientific Publishing Co.; 2012 [cited 2012 Nov 3]. Chapter 18. } \\
\text { Available from: } \\
\text { http://www.worldscientific.com/doi/pdf/10.1142/9789814324496_0 } \\
\text { 018 }\end{array}$ \\
\hline
\end{tabular}

\section{Government and other reports}

- Follow these examples closely for all layout, punctuation, spacing, and capitalization.

- Enter author's surname, followed by no more than 2 initials.

- Give all authors and separate each by a comma and space.

- Where the author is an organization, quote the full name of the organization, omitting the word "The" if preceding the name. Follow the name with the country of origin in parenthesis ( ) using only the two letter country code.

- Where an author and organization are cited, use the author's name. Add the organization's name at your discretion.

- If there are no authors, only editors, list all editors, followed by a comma and the word editor(s).

- Only the first word of the article title and words that normally begin with a capital letter are capitalized.

- The place of publication is the city in which the report was published.

- Include page numbers in an abbreviated format. e.g.: p. 12-25. Where appropriate abbreviate e.g. p. 241-8.

- For electronic reports include the DOI if it is given and place it after the URL.

- Abbreviate months to their first 3 letters.

\begin{tabular}{|l|l|}
\hline Government & Author AA, Author BB. Title of report. Place of publication: Publisher;
\end{tabular}


Rowe IL, Carson NE. Medical manpower in Victoria. East Bentleigh (AU): Monash University, Department of Community Practice; 1981. 35 p. Report No.: 4.

\section{Dictionaries and encyclopedias}

- Follow these examples closely for all layout, punctuation, spacing, and capitalization.

- Include the DOI at the end of the reference if it is available.

\begin{tabular}{|l|l|}
\hline $\begin{array}{l}\text { Article from } \\
\text { online reference } \\
\text { work }\end{array}$ & $\begin{array}{l}\text { Title of encyclopedia [Internet]. Place of publication: Publisher; year. } \\
\text { Title of article; [updated YYYY Mon DD; cited YYYY Mon DD]; [\# of } \\
\text { pages/screens]. Available from: URL }\end{array}$ \\
\hline & $\begin{array}{l}\text { A.D.A.M. medical encyclopedia [Internet]. Atlanta (GA): A.D.A.M., } \\
\text { Inc.; c2005. Ear barotrauma; [updated } 2006 \text { Oct 20; cited } 2006 \text { Nov } \\
\text { 16]; [about 4 screens]. Available from: } \\
\text { http://www.nIm.nih.gov/medlineplus/ency/article/001064.htm }\end{array}$ \\
\hline $\begin{array}{l}\text { Article from } \\
\text { electronic drug } \\
\text { guide }\end{array}$ & $\begin{array}{l}\text { Title of work [Internet]. Place of publication: Publisher/Website; year. } \\
\text { Name of drug: [revision/review date; cited YYY Mon DD]; [\# of } \\
\text { pages/screens]. Available from: URL }\end{array}$ \\
\hline & $\begin{array}{l}\text { AHFS consumer medication Information [Internet]. Bethesda (MD): } \\
\text { American Society of Health-System Pharmacists, Inc.; C2008. } \\
\text { Protriptyline; [revised 2007 Aug 1; reviewed 2007 Aug 1; cited 2008 } \\
\text { Oct 2]; [about 5 p.]. Available from: } \\
\text { http://www.nlm.nih.gov/medlineplus/druginfo/meds/a604025.html }\end{array}$ \\
\hline
\end{tabular}

\section{Audio visual media}

\begin{tabular}{|l|l|}
\hline DVD's & $\begin{array}{l}\text { Author A. Title [Format]. Place of publication: Publisher; year of } \\
\text { publication. Item description. }\end{array}$ \\
\hline $\begin{array}{l}\text { Subbarao M. Tough cases in carotid stenting [DVD]. Woodbury (CT): } \\
\text { Cine-Med, Inc.; 2003. 1 DVD: sound, color, 4 3/4 in. }\end{array}$ \\
\hline $\begin{array}{l}\text { Video file eg. } \\
\text { veb streaming }\end{array}$ & $\begin{array}{l}\text { Author, A. Title [format]. Place of publication: publisher; date of } \\
\text { publication [date it was viewed]. Available from: website address }\end{array}$ \\
\hline & $\begin{array}{l}\text { Silverstein O. Mothers and sons: the crucial connection [web } \\
\text { streaming video]. Hanover (USA): Microtraining Associates; } 2005 \\
\text { [cited 2010 May 27]. Available from: } \\
\text { http://ctiv.alexanderstreet.com/View/536289 }\end{array}$ \\
\hline
\end{tabular}

\section{From the Internet}

- Follow these examples closely for all layout, punctuation, spacing, and capitalization.

- Author names should be listed in the order they appear on the site.

- Reproduce the title of a homepage as closely as possible to the wording on the screen. 


\section{MAJALAH KEDOKTERAN ANDALAS}

- Place the word Internet in square brackets following the title (and content type if present).

- Place of publication is defined as the city where the homepage is published. If a place, publisher, date unknown use [place unknown], for example.

- The publisher is defined as the individual or organization issuing the homepage.

- Use the date of publication as the date the page was first published on the internet, always give the year.

- Date of update/revision - Always give the year and include the date/month, if provided, after the year.

- Include the date that you saw the page on the internet.

- Begin with the phrase "Available from". Insert the URL in its entirety. End with a period only if the URL ends with a slash, otherwise, end with no punctuation.

\begin{tabular}{|c|c|}
\hline $\begin{array}{l}\text { Webpage: } \\
\text { a) homepage } \\
\text { b) part of the } \\
\text { website }\end{array}$ & $\begin{array}{l}\text { a) Author/organization's name. Title of the page [Internet]. Place of } \\
\text { publication: Publisher's name; Date or year of publication [updated } \\
\text { year month day; cited year month day]. Available from: URL } \\
\text { b) Title of the homepage [Internet]. Place of publication: Publisher's } \\
\text { name; Date or year of publication. Title of specific page/part; Date of } \\
\text { publication of part [Date cited of part]; [location or pagination of } \\
\text { part]. Available from: URL }\end{array}$ \\
\hline & $\begin{array}{l}\text { a) Diabetes Australia. Diabetes globally [Internet]. Canberra ACT: } \\
\text { Diabetes Australia; } 2012 \text { [updated } 2012 \text { June 15; cited } 2012 \text { Nov 5]. } \\
\text { Available from: http://www.diabetesaustralia.com.au/en/ } \\
\text { Understanding-Diabetes/Diabetes-Globally/ } \\
\text { b) Australian Medical Association [Internet]. Barton ACT: AMA; } \\
\text { c1995-2012. Junior doctors and medical students call for urgent } \\
\text { solution to medical training crisis; } 2012 \text { Oct } 22 \text { [cited } 2012 \text { Nov 5]; } \\
\text { [about } 3 \text { screens]. Available from: https://ama.com.au/media/junior- } \\
\text { doctors -and-medical-students-call-urgentsolution- } \\
\text { medical-training-crisis }\end{array}$ \\
\hline $\begin{array}{l}\text { Image from the } \\
\text { web }\end{array}$ & $\begin{array}{l}\text { Note: If the title of the image is not shown construct a title that } \\
\text { describes the image shown. Use enough words to make the } \\
\text { constructed title meaningful. Place the constructed title in square } \\
\text { brackets. } \\
\text { Author or organization. Title [Image on internet]. Place of publication: } \\
\text { Publisher's name; date of publication [date cited]. Available from: } \\
\text { URL }\end{array}$ \\
\hline & $\begin{array}{l}\text { Centres for Disease Control and Prevention. Shingles on face. [Image } \\
\text { on the internet]. } 2011 \text { [updated } 2011 \text { Jan 10; cited } 2012 \text { Nov 6]. } \\
\text { Available } \\
\text { from: http://www.cdc.gov/shingles/about/photos.html }\end{array}$ \\
\hline
\end{tabular}




\section{MAJALAH KEDOKTERAN ANDALAS}

\section{University course materials}

Note: Not all lecturers approve the citation of unit materials, such as lecture slides, in assignments. Check with your lecturer first to see if these resources are acceptable.

\begin{tabular}{|l|l|}
\hline $\begin{array}{l}\text { Lecture notes on } \\
\text { Moodle }\end{array}$ & $\begin{array}{l}\text { Author, A.A. Title of lecture [format]. Place of Publication: Publisher; } \\
\text { Date of Publication [Date cited]. Available from: 'website address' }\end{array}$ \\
\hline & $\begin{array}{l}\text { Cloe, J. The normal distribution [Lecture notes on the internet]. } \\
\text { Melbourne: Monash University, Faculty of Medicine, Nursing and } \\
\text { Health Sciences; } 2012 \text { [cited 2012 Jun 26]. Available from: } \\
\text { http://moodle.vle.monash.edu.au }\end{array}$ \\
\hline $\begin{array}{l}\text { Custom textbook } \\
\text { or unit reader }\end{array}$ & $\begin{array}{l}\text { Author, A.A. Title of article. Publication details including original } \\
\text { pages. Reprinted in: Smith, B editor, Title of course material. Place of } \\
\text { publication: Publisher; Year of publication. }\end{array}$ \\
\hline & $\begin{array}{l}\text { Shaffer, E, Brenner J. International trade agreements: hazards to } \\
\text { health? International Journal of Health Services. 2004;34(3):467-481. } \\
\text { Reprinted in: BTW3201 International Trade Law course materials } \\
\text { 2011. Melbourne: Monash University; 2011. }\end{array}$ \\
\hline
\end{tabular}

\section{Sample reference list}

\section{Reference}

1. O'Campo P, Dunn JR, editors. Rethinking social epidemiology: towards a science of change. Dordrecht: Springer; 2012. 348 p.

2. Schiraldi GR. Post-traumatic stress disorder sourcebook: a guide to healing, recovery, and growth [Internet]. New York: McGraw-Hill; 2000 [cited 2006 Nov 6]. 446 p. Available from: http://books.mcgraw-hill.com/getbook.php?isbn=0071393722\&template=\#toc DOI: 10.1036/0737302658

3. Halpen-Felsher BL, Morrell HE. Preventing and reducing tobacco use. In: Berlan ED, Bravender T, editors. Adolescent medicine today: a guide to caring for the adolescent patient [Internet]. Singapore: World Scientific Publishing Co.; 2012 [cited 2012 Nov 3]. Chapter 18. Available from: http://www.worldscientific.com/doi/pdf/10.1142/9789814324496_0018

4. Stockhausen L, Turale S. An explorative study of Australian nursing scholars and contemporary scholarship. J Nurs Scholarsh [Internet]. 2011 Mar [cited 2013 Feb 19];43(1):89-96. Available from:

http://search.proquest.com.ezproxy.lib.monash.edu.au/docview/858241255?accountid $=12528$

5. Kanneganti P, Harris JD, Brophy RH, Carey JL, Lattermann C, Flanigan DC. The effect of smoking on ligament and cartilage surgery in the knee: a systematic review. Am J Sports Med [Internet]. 2012 Dec [cited 2013 Feb 19];40(12):2872-8. Available from: http://ajs.sagepub.com/content/40/12/2872 DOI: 10.1177/0363546512458223 
6. Subbarao M. Tough cases in carotid stenting [DVD]. Woodbury (CT): Cine-Med, Inc.; 2003. 1 DVD: sound, color, $43 / 4$ in.

7. Stem cells in the brain [television broadcast]. Catalyst. Sydney: ABC; 2009 Jun 25. 
This reference guide is written based on the adaptation of Vancouver Citing and Referencing Style by Monash University Library, with some adjustments for MKA's Author Guidelines purposes. You may wish to consult this source directly for additional information or examples. 